\title{
Anti-inflammatory properties of some novel thiazolo[4,5-b]pyridin-2-ones
}

Taras Chaban ${ }^{1}$, Vasyl Matiychuk², Olexandra Komarytsya ${ }^{3}$, Iryna Myrkoํ․ Ihor Chaban ${ }^{4}$, Volodymyr Ogurtsov ${ }^{1}$, Ihor Nektegaev ${ }^{5}$

1 Department of General, Bioinorganic, Physical and Colloidal Chemistry, Danylo Halytsky Lviv National Medical University, Pekarska 69, Lviv, 79010, Ukraine

2 Department of Organic Chemistry, Ivan Franko National University of Lviv, 6 Kyryla i Mefodia, Lviv, 79005, Ukraine

3 Department of oral surgery and prosthetic dentistry, Danylo Halytsky Lviv National Medical University, Pekarska 69, Lviv, 79010, Ukraine

4 Department of Pharmaceutical Chemistry FPGE, Danylo Halytsky Lviv National Medical University, Pekarska 69, Lviv, 79010, Ukraine

5 Department of Pharmacology, Danylo Halytsky Lviv National Medical University, Pekarska 69, Lviv, 79010, Ukraine

Corresponding author: Taras Chaban (chabantaras@ukr.net)

Received 10 August 2019 • Accepted 24 January 2020 • Published 28 August 2020

Citation: Chaban T, Matiychuk V, Komarytsya O, Myrko I, Chaban I, Ogurtsov V, Nektegaev I (2020) Anti-inflammatory properties of some novel thiazolo[4,5-b]pyridin-2-ones. Pharmacia 67(3): 121-127. https://doi.org/10.3897/pharmacia.67.e38969

\section{Abstract}

Synthesis of novel $\mathrm{N}^{3}$ and $\mathrm{C}^{5}$ substituted thiazolo[4,5-b]pyridin-2-ones was carried out on the basis of [3+3]-cyclocodensation, acylation and alkylation reactions. The structures of the obtained compounds were confirmed by ${ }^{1} \mathrm{H}$ NMR spectroscopy, and elemental analysis. The anti-inflammatory action of novel thiazolo[4,5- $b]$ pyridine-2-one derivatives was evaluated in vivo employing the carrageenan-induced rat paw edema method. When compared with Ibuprofen, some our compounds were found to be more potent.

Graphical abstract

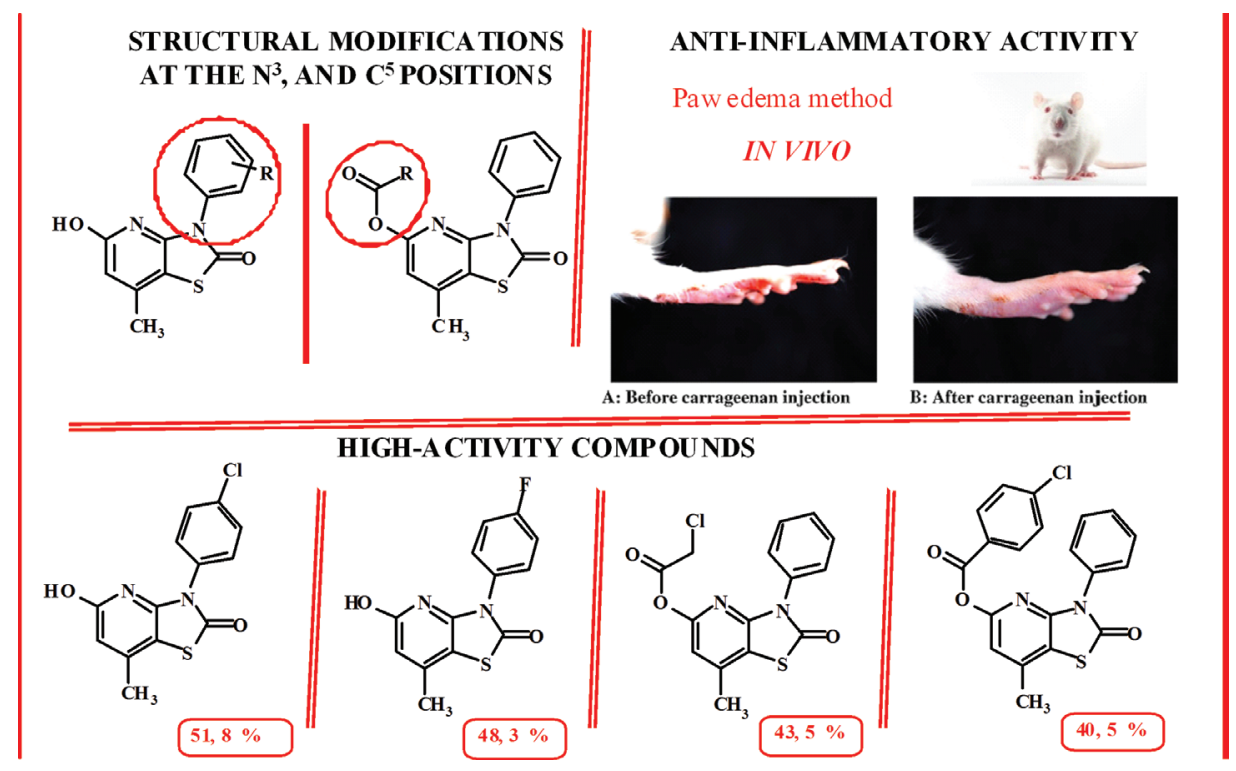




\section{Keywords}

anti-inflammatory activity, organic synthesis, thiazolo[4,5- $b]$ pyridines

\section{Introduction}

Inflammation is a major pathogenetic component of many diseases of different etiology and one of the most important problems of general pathology and clinic. This reaction of the body to damage, is involved in the formation of many diseases. The problem of the pharmacological regulation of inflammation is relevant to modern medicine (Brenner and Krakauer 2003). There is a considerable amount of medication used to treat inflammation. Non-steroidal anti-inflammatory drugs, which combine a whole range of properties, displaying anti-inflammatory, analgesic, antipyretic activity are in particular demand (Bacchi et al. 2012). However, they all have ulcerogenic properties to varying degrees (Al-Shidhani et al. 2015). In order to overcome these restrictions worldwide, the search for new effective and safe anti-inflammatory drugs is continuing.

The development of chemistry of heterocyclic compounds is largely due to the practical direction of research. It is sufficient to note that among the most well-known and widely used drugs, more than $60 \%$ belong to heterocyclic compounds (Taylor et al. 2016), so the work in this direction is rapidly developing and relevant. In particular, there is growing interest in nitrogen-containing fused heterocyclic systems, as many of them exhibit broad-spectrum biological activity (Smirnova et al. 2006; Chaban et al. 2017a, 2018a). Pyridine derivatives make up a large part of the modern drug arsenal. Of the 1.5 thousand most commonly used drugs, more than $10 \%$ account for the compounds having the pyridine ring (Ali Altaf et al. 2015). Equally interesting are 4-thiazolidones (Abhinit et al. 2009; Lozynska et al. 2015; Chhabria et al. 2016; Tymoshuk et al. 2019). Thiazolidone derivatives anelated with the pyridine cycle, in particular thiazolopyridine, are of particular interest to researchers because these compounds exhibit different types of biological activity. Among them were identified substances with antioxidant (Chaban et al. 2013, 2019a; Klenina et al. 2013, 2017), fungicidal (Marzoog and Al-Thebeiti 2000), anti-inflammatory (Chaban et al. 2016, 2017b, 2018b), anti-mitotic (Victor et al. 2017), tuberculostatic (Chaban et al. 2014), herbicidal (Hegde and Mahoney 1993) and antitumor (Chaban et al. 2012a) activities, agonists of H3-histamine receptors (Walczyn'ski et al. 2005), antagonists of metabotropic glutamate receptors 5 (mGluR5) (Lin et al. 2009), substances with high inhibitory activity against epidermal growth factor receptors (Komoriya et al. 2006) and several other enzymes (Singh et al. 1995). Given the above synthesis of new thiazolopyridines, as well as the pharmacological screening of the anti-inflammatory activity of the newly synthesized compounds is an interesting and relevant direction.

\section{Experimental part Materials and methods}

All chemicals were of analytical grade and commercially available. All reagents and solvents were used without further purification and drying.

All the melting points were determined in an open capillary and are uncorrected. ${ }^{1} \mathrm{H}$ - spectra were recorded on a Varian Mercury $400\left(400 \mathrm{MHz}\right.$ for $\left.{ }^{1} \mathrm{H}\right)$ instrument with TMS or deuterated solvent as an internal reference. Mass spectra were run using Agilent 1100 series LC/MSD, Agilent Technologies Inc. with an API-ES/APCI ionization mode. Satisfactory elemental analyses were obtained for new compounds $(\mathrm{C} \pm 0.17, \mathrm{H} \pm 0.21, \mathrm{~N} \pm 0.19)$. Ibuprofen was purchased from a medical store.

\section{Chemistry}

General procedure for the synthesis of 3-aryl-5-hydroxy-7methyl-3H-thiazolo[4,5-b]pyridin-2-ones (1-8). Metallic Sodium (109 $\mathrm{mmol}$ ) was dissolved in anhydrous methanol $(150 \mathrm{ml})$, to the resulting solution was added the corresponding 3-aryl-4-iminothiazolidin-2-one $(50 \mathrm{mmol})$ and acetoacetic ether $(8.5 \mathrm{ml})$ at $20^{\circ} \mathrm{C}$. The mixture is left for 5 days, stirring on a magnetic stirrer. Then it is acidified with acetate to $\mathrm{pH} \sim 5$, diluted five times with water, the precipitate is filtered off, washed with water and dried. Recrystallized from acetic acid. The obtained substances are white, gray or yellowish crystalline powders, well soluble in DMF, DMSO, alkali solutions, low in benzene, toluene, alcohols; bad - in other organic solvents and water.

5-Hydroxy-7-methyl-3-phenyl-3H-thiazolo [4,5-b] pyridin-2-one (1). Yield: $65 \%, \mathrm{mp} .=244{ }^{\circ} \mathrm{C} .{ }^{1} \mathrm{H}$ NMR (400 MHz, DMSO-d6) d $2.51\left(\mathrm{~s}, 3 \mathrm{H}, \mathrm{CH}_{3}\right), 6.96(\mathrm{t}$, $J=7.3 \mathrm{~Hz}, 1 \mathrm{H}, \mathrm{Py}), 7.28(\mathrm{t}, J=7.4 \mathrm{~Hz}, J=7.7 \mathrm{~Hz}, 2 \mathrm{H}$, $\left.\mathrm{C}_{6} \mathrm{H}_{5}\right), 7.45\left(\mathrm{~d}, \mathrm{~J}=8.1 \mathrm{~Hz}, 3 \mathrm{H}, \mathrm{C}_{6} \mathrm{H}_{5}\right), 8.67(\mathrm{~s}, 1 \mathrm{H}, \mathrm{OH})$. Anal. calcd. for $\mathrm{C}_{13} \mathrm{H}_{10} \mathrm{~N}_{2} \mathrm{O}_{2} \mathrm{~S} \%$ : C 60.45, H 3.90, N 10.85 . Found: C 60.06, H 3.84, N 10.73.

5-Hydroxy-7-methyl-3-(4-nitro-phenyl)-3H-thiazolo[4,5-b]pyridin-2-one (2). Yield: $56 \%, \mathrm{mp} .=212{ }^{\circ} \mathrm{C} .{ }^{1} \mathrm{H}$ NMR (400 MHz, DMSO-d6) d 2.55 (s, 3H, $\left.\mathrm{CH}_{3}\right), 7.01$ (s, $1 \mathrm{H}, \mathrm{Py}), 7.29\left(\mathrm{~d}, 2 \mathrm{H}, J=8.2 \mathrm{~Hz}, \mathrm{C}_{6} \mathrm{H}_{4}\right), 7.53(\mathrm{~d}, 2 \mathrm{H}$, $\left.J=8.2 \mathrm{~Hz}, \mathrm{C}_{6} \mathrm{H}_{4}\right), 8.71(\mathrm{~s}, 1 \mathrm{H}, \mathrm{OH})$. Anal. calcd. for: $\mathrm{C}_{13} \mathrm{H}-$ ${ }_{9} \mathrm{~N}_{3} \mathrm{O}_{4}$ S: C 51.48, H 2.99, N 13.85. Found: C 51.16, H 3.05, $\mathrm{N} 13.69$.

3-(4-Chloro-phenyl)-5-hydroxy-7-methyl-3H-thiazolo[4,5-b]pyridin-2-one (3). Yield: $51 \%, \mathrm{mp}=206{ }^{\circ} \mathrm{C} .{ }^{1} \mathrm{H}$ NMR (400 MHz, DMSO-d6) d $2.51\left(\mathrm{~s}, 3 \mathrm{H}, \mathrm{CH}_{3}\right), 6.99$ (s, $1 \mathrm{H}$, Py), 7.19 (d, 2H, $\left.J=7.8 \mathrm{~Hz}, \mathrm{C}_{6} \mathrm{H}_{4}\right), 7.45(\mathrm{~d}, 2 \mathrm{H}, J=8.1 \mathrm{~Hz}$, $\left.\mathrm{C}_{6} \mathrm{H}_{4}\right), 8.68$ (s, $\left.1 \mathrm{H}, \mathrm{OH}\right)$. Anal. calcd. for: $\mathrm{C}_{13} \mathrm{H}_{9} \mathrm{ClN}_{2} \mathrm{O}_{2} \mathrm{~S}: \mathrm{C}$ 53.34, H 3.10, N 9.57. Found: C 52.98, H 3.14, N 9.61. 
3-(4-Fluoro-phenyl)-5-hydroxy-7-methyl-3H-thiazolo[4,5-b]pyridin-2-one (4). Yield: $59 \%, \mathrm{mp} .=223{ }^{\circ} \mathrm{C} .{ }^{1} \mathrm{H}$ NMR (400 MHz, DMSO-d6) d 2.52 (s, 3H, $\left.\mathrm{CH}_{3}\right), 7.03$ (s, $1 \mathrm{H}, \mathrm{Py}), 7.25\left(\mathrm{~d}, 2 \mathrm{H}, J=7.7 \mathrm{~Hz}, \mathrm{C}_{6} \mathrm{H}_{4}\right), 7.51(\mathrm{~d}, 2 \mathrm{H}, J=8.4$ $\left.\mathrm{Hz}, \mathrm{C}_{6} \mathrm{H}_{4}\right), 8.71(\mathrm{~s}, 1 \mathrm{H}, \mathrm{OH})$. Anal. calcd. for: $\mathrm{C}_{13} \mathrm{H}_{9} \mathrm{~F}-$ $\mathrm{N}_{2} \mathrm{O}_{2}$ S: C 56.51, H 3.28, N 10.14. Found: C C 56.08, H 3.21, N 10.07.

5-Hydroxy-7-methyl-3-p-tolyl-3H-thiazolo[4,5-b] pyridin-2-one (5). Yield: $63 \%, \mathrm{mp} .=232{ }^{\circ} \mathrm{C} .{ }^{1} \mathrm{H}$ NMR (400 MHz, DMSO-d6) d 2.49 (s, 3H, $\left.\mathrm{CH}_{3}\right), 2.67$ (s, 3H, $\left.\mathrm{C}_{6} \mathrm{H}_{4}-\mathrm{CH}_{3}\right), 6.99(\mathrm{~s}, 1 \mathrm{H}, \mathrm{Py}), 7.23\left(\mathrm{~d}, 2 \mathrm{H}, J=7.8 \mathrm{~Hz}, \mathrm{C}_{6} \mathrm{H}_{4}\right)$, $7.57\left(\mathrm{~d}, 2 \mathrm{H}, J=8.3 \mathrm{~Hz}, \mathrm{C}_{6} \mathrm{H}_{4}\right), 8.69(\mathrm{~s}, 1 \mathrm{H}, \mathrm{OH})$. Anal. calcd. for: $\mathrm{C}_{14} \mathrm{H}_{12} \mathrm{~N}_{2} \mathrm{O}_{2} \mathrm{~S}$ : C 61.75, H 4.44, N 10.29. Found: C 62.05, H 4.12, N 10.34 .

5-Hydroxy-3-(4-hydroxy-phenyl)-7-methyl-3H-thiazolo[4,5-b]pyridin-2-one (6). Yield: $68 \%, \mathrm{mp} .=208{ }^{\circ} \mathrm{C} .{ }^{1} \mathrm{H}$ NMR (400 MHz, DMSO-d6) d 2.52 (s, 3H, CH $), 7.00$ (s, $1 \mathrm{H}, \mathrm{Py}), 7.30\left(\mathrm{~d}, 2 \mathrm{H}, J=8.2 \mathrm{~Hz}, \mathrm{C}_{6} \mathrm{H}_{4}\right), 7.58(\mathrm{~d}, 2 \mathrm{H}$, $\left.J=7.9 \mathrm{~Hz}, \mathrm{C}_{6} \mathrm{H}_{4}\right), 8.70(\mathrm{~s}, 1 \mathrm{H}, \mathrm{OH}), 9.83\left(\mathrm{~s}, 1 \mathrm{H}, \mathrm{C}_{6} \mathrm{H}_{4}-\mathrm{OH}\right)$. Anal. calcd. for: $\mathrm{C}_{13} \mathrm{H}_{10} \mathrm{~N}_{2} \mathrm{O}_{3} \mathrm{~S}$ : C 56.92, $\mathrm{H} 3.67, \mathrm{~N} 10.21$. Found: C 57.12, H 3.61, N 10.25.

5-Hydroxy-7-methyl-3-m-tolyl-3H-thiazolo[4,5-b] pyridin-2-one (7). Yield: 54\%, mp. $=244{ }^{\circ} \mathrm{C} .{ }^{1} \mathrm{H}$ NMR (400 MHz, DMSO-d6) d 2.46 (s, 3H, $\left.\mathrm{CH}_{3}\right), 2.61$ (s, 3H, $\left.\mathrm{C}_{6} \mathrm{H}_{4}-\mathrm{CH}_{3}\right), 7.00(\mathrm{~s}, 1 \mathrm{H}, \mathrm{Py}), 7.08\left(\mathrm{~d}, 1 \mathrm{H}, J=9.7 \mathrm{~Hz}, \mathrm{C}_{6} \mathrm{H}_{4}\right)$, $7.16\left(\mathrm{t}, 1 \mathrm{H}, J=8.0 \mathrm{~Hz}, \mathrm{C}_{6} \mathrm{H}_{4}\right), 7.25\left(\mathrm{t}, 1 \mathrm{H}, J=8.0 \mathrm{~Hz}, \mathrm{C}_{6} \mathrm{H}_{4}\right)$, $7.84\left(\mathrm{~d}, 1 \mathrm{H}, J=7.5 \mathrm{~Hz}, \mathrm{C}_{6} \mathrm{H}_{4}\right), 8.66(\mathrm{~s}, 1 \mathrm{H}, \mathrm{OH})$. Anal. calcd. for: $\mathrm{C}_{14} \mathrm{H}_{12} \mathrm{~N}_{2} \mathrm{O}_{2} \mathrm{~S}$ : C 61.75, $\mathrm{H} 4.44, \mathrm{~N}$ 10.29. Found: C 61.88, H 4.35, N 10.28.

5-Hydroxy-3-(3-hydroxy-phenyl)-7-methyl-3H-thiazolo[4,5-b]pyridin-2-one (8). Yield: $60 \%, \mathrm{mp} .=215{ }^{\circ} \mathrm{C} .{ }^{1} \mathrm{H}$ NMR (400 MHz, DMSO-d6) d 2.49 (s, 3H, CH $), 6.96$ (s, $1 \mathrm{H}$, Py), 7.87 (d, $\left.1 \mathrm{H}, J=8.3 \mathrm{~Hz}, \mathrm{C}_{6} \mathrm{H}_{4}\right), 7.94(\mathrm{~d}, 1 \mathrm{H}, J=7.0 \mathrm{~Hz}$, $\left.\mathrm{C}_{6} \mathrm{H}_{4}\right), 8.43-8.45\left(\mathrm{~m}, 2 \mathrm{H}, \mathrm{C}_{6} \mathrm{H}_{4}\right), 8.68$ (s, $\left.1 \mathrm{H}, \mathrm{OH}\right), 10.01$ (s, $1 \mathrm{H}, \mathrm{C}_{6} \mathrm{H}_{4}-\mathrm{OH}$ ). Anal. calcd. for: $\mathrm{C}_{13} \mathrm{H}_{10} \mathrm{~N}_{2} \mathrm{O}_{3} \mathrm{~S}$ : C 56.92, $\mathrm{H}$ 3.67, N 10.21. Found: C 57.12, H 3.61, N 10.25.

General procedure for the production of acylation products of 5-hydroxy-7-methyl-3-phenyl-3H-thiazolo[4,5-b] pyridin-2-one by aliphatic chloroanhydride to form compounds 9-11. In a flat bottom flask dissolve $10 \mathrm{mmol}$ of compound 1 in $10 \mathrm{ml}$ of anhydrous dioxane. To the resulting solution was added a solution consisting of $10 \mathrm{mmol}$ of the corresponding aliphatic chloroanhydride and $10 \mathrm{mmol}$ of triethylamine in $10 \mathrm{ml}$ of dioxane. Maintain for 10 minutes in a drying oven at a temperature of $100{ }^{\circ} \mathrm{C}$ and poured into water. After recrystallization from acetic acid, the white or yellowish powders are soluble when heated in ethanol, DMF, acetic acid.

Acetic acid 7-methyl-2-oxo-3-phenyl-2,3-dihydro-thiazolo[4,5-b]pyridin-5-yl ester (9). Yield: $76 \%, \mathrm{mp} .=235$ ${ }^{\circ} \mathrm{C} .{ }^{1} \mathrm{H}$ NMR (400 MHz, DMSO-d6) d 2.30 (s, 3H, $\mathrm{CH}_{3}$ ), 2.36 (s, 3H, $\left.\mathrm{CH}_{3}-\mathrm{CO}\right), 6.92(\mathrm{~s}, 1 \mathrm{H}, \mathrm{Py}), 7.30(\mathrm{t}, J=7.4 \mathrm{~Hz}$, $\left.J=7.7 \mathrm{~Hz}, 2 \mathrm{H}, \mathrm{C}_{6} \mathrm{H}_{5}\right), 7.48\left(\mathrm{~d}, J=8.1 \mathrm{~Hz}, 3 \mathrm{H}, \mathrm{C}_{6} \mathrm{H}_{5}\right)$. Anal. calcd. for: $\mathrm{C}_{15} \mathrm{H}_{12} \mathrm{~N}_{2} \mathrm{O}_{3} \mathrm{~S}$ : C 59.99, H 4.03, N 9.33. Found: C 60.18, H 4.12, N 9.39.

Chloro-acetic acid 7-methyl-2-oxo-3-phenyl-2,3-dihydro-thiazolo[4,5-b]pyridin-5-yl ester (10). Yield: 73\%, $\mathrm{mp} .=188{ }^{\circ} \mathrm{C} .{ }^{1} \mathrm{H}$ NMR (400 MHz, DMSO-d6) d 2.35 (s, 3H, $\left.\mathrm{CH}_{3}\right), 4.72\left(\mathrm{~s}, 2 \mathrm{H}, \mathrm{CH}_{2}\right), 6.94(\mathrm{~s}, 1 \mathrm{H}, \mathrm{Py}), 7.28(\mathrm{t}$, $\left.J=7.4 \mathrm{~Hz}, J=7.7 \mathrm{~Hz}, 2 \mathrm{H}, \mathrm{C}_{6} \mathrm{H}_{5}\right), 7.46(\mathrm{~d}, J=8.1 \mathrm{~Hz}, 3 \mathrm{H}$, $\mathrm{C}_{6} \mathrm{H}_{5}$ ). Anal. calcd. for: $\mathrm{C}_{15} \mathrm{H}_{11} \mathrm{ClN}_{2} \mathrm{O}_{3} \mathrm{~S}$ : C 53.82, H 3.31, N 8.37. Found: C 53.71, H 3.28, N 8.41.

Butyric acid 7-methyl-2-oxo-3-phenyl-2,3-dihydro-thiazolo[4,5-b]pyridin-5-yl ester (11). Yield: 60\%, $\mathrm{mp} .=172{ }^{\circ} \mathrm{C} .{ }^{1} \mathrm{H}$ NMR (400 MHz, DMSO-d6) d $1.02(\mathrm{t}$, $\left.J=7.3 \mathrm{~Hz}, 3 \mathrm{H}, \mathrm{CH}_{3}-\mathrm{CH}_{2}-\mathrm{CH}_{2}-\mathrm{CO}\right), 1.66-1.71(\mathrm{~m}, 2 \mathrm{H}$, $\left.\mathrm{CH}_{3}-\mathrm{CH}_{2}-\mathrm{CH}_{2}-\mathrm{CO}\right), 2.35$ (s, $\left.3 \mathrm{H}, \mathrm{CH}_{3}\right), 4.72\left(\mathrm{~s}, 2 \mathrm{H}, \mathrm{CH}_{2}\right)$, $2.62\left(\mathrm{t}, J=7.1 \mathrm{~Hz}, 3 \mathrm{H}, \mathrm{CH}_{3}-\mathrm{CH}_{2}-\mathrm{CH}_{2}-\mathrm{CO}\right), 6.90(\mathrm{~s}, 1 \mathrm{H}$, Py), $7.31\left(\mathrm{t}, J=7.4 \mathrm{~Hz}, J=7.7 \mathrm{~Hz}, 2 \mathrm{H}, \mathrm{C}_{6} \mathrm{H}_{5}\right), 7.47$ (d, $\left.J=8.1 \mathrm{~Hz}, 3 \mathrm{H}, \mathrm{C}_{6} \mathrm{H}_{5}\right)$. Anal. calcd. for: $\mathrm{C}_{16} \mathrm{H}_{17} \mathrm{~N}_{2} \mathrm{O}_{3} \mathrm{~S}: \mathrm{C}$ 62.18, H 4.91, N 8.53. Found: C 62.32, H 5.00, N 8.60.

General procedure for the production of acylation products of 5-hydroxy-7-methyl-3-phenyl-3H-thiazolo[4,5-b] pyridin-2-one by aromatic chloroanhydride to form compounds 12-16. Compound $\mathbf{1}$ ( $5 \mathrm{mmol}$ ) was added to a solution of pyridine $(20 \mathrm{ml})$ and the corresponding aromatic chloroanhydride $(5 \mathrm{mmol})$. The reaction mixture was refluxed for $30 \mathrm{~min}$. Upon cooling, the crystalline precipitate was filtered off, washed with acetate and dried. The compounds obtained were crystallized from acetate or ethanol. These are white, gray or cream substances, poorly soluble in water and organic solvents, soluble in acetate, DMF and DMSO.

4-Chloro-benzoic acid 7-methyl-2-oxo-3-phenyl-2,3-dihydro-thiazolo[4,5-b]pyridin-5-yl ester (12). Yield: 63\%, $\mathrm{mp} .=221{ }^{\circ} \mathrm{C} .{ }^{1} \mathrm{H}$ NMR (400 MHz, DMSO-d6) d 2.37 (s, $\left.3 \mathrm{H}, \mathrm{CH}_{3}\right), 7.07$ (s, $\left.1 \mathrm{H}, \mathrm{Py}\right), 7.28(\mathrm{t}, J=7.4 \mathrm{~Hz}, J=7.7 \mathrm{~Hz}, 2 \mathrm{H}$, $\left.\mathrm{C}_{6} \mathrm{H}_{5}\right), 7.44\left(\mathrm{~d}, J=8.1 \mathrm{~Hz}, 3 \mathrm{H}, \mathrm{C}_{6} \mathrm{H}_{5}\right), 7.66(\mathrm{~d}, J=8.5 \mathrm{~Hz}$, $\left.2 \mathrm{H}, \mathrm{C}_{6} \mathrm{H}_{4}\right), 8.09\left(\mathrm{~d}, J=8.5 \mathrm{~Hz}, 2 \mathrm{H}, \mathrm{C}_{6} \mathrm{H}_{4}\right)$. Anal. calcd. for: $\mathrm{C}_{20} \mathrm{H}_{13} \mathrm{ClN}_{2} \mathrm{O}_{3} \mathrm{~S}$ : C 60.53, H 3.30, N 7.06. Found: C 60.66, $\mathrm{H} 3.27, \mathrm{~N} 6.99$.

4-Benzyloxy-benzoic acid 7-methyl-2-oxo-3-phenyl-2,3-dihydro-thiazolo[4,5-b]pyridin-5-yl ester (13). Yield: $65 \%, \mathrm{mp} .=191{ }^{\circ} \mathrm{C} .{ }^{1} \mathrm{H}$ NMR $(400 \mathrm{MHz}, \mathrm{DMSO}-\mathrm{d} 6)$ d $2.33\left(\mathrm{~s}, 3 \mathrm{H}, \mathrm{CH}_{3}\right), 7.02(\mathrm{~s}, 1 \mathrm{H}, \mathrm{Py}), 7.19(\mathrm{~d}, J=8.4 \mathrm{~Hz}$, $\left.2 \mathrm{H}, \mathrm{C}_{6} \mathrm{H}_{4}\right), 7.25\left(\mathrm{t}, J=7.3 \mathrm{~Hz}, J=7.6 \mathrm{~Hz}, 2 \mathrm{H}, \mathrm{C}_{6} \mathrm{H}_{5}\right), 7.39$ (d, $\left.J=8.0 \mathrm{~Hz}, 3 \mathrm{H}, \mathrm{C}_{6} \mathrm{H}_{5}\right), 7.44\left(\mathrm{~d}, J=7.2 \mathrm{~Hz}, 2 \mathrm{H}, \mathrm{CH}_{2}-\mathrm{C}_{6} \mathrm{H}_{5}\right)$, $7.49\left(\mathrm{~d}, J=6.9 \mathrm{~Hz}, 3 \mathrm{H}, \mathrm{CH}_{2}-\mathrm{C}_{6} \mathrm{H}_{5}\right), 8.08$ (д, $J=8.3$ Гц, $2 \mathrm{H}$, $\mathrm{C}_{6} \mathrm{H}_{4}$ ). Anal. calcd. for: $\mathrm{C}_{27} \mathrm{H}_{20} \mathrm{~N}_{2} \mathrm{O}_{4} \mathrm{~S}: \mathrm{C} 69.22, \mathrm{H} 4.30, \mathrm{~N}$ 5.98. Found: C C 70.01, H 4.25, N 6.02.

1-(2,4-Dimethyl-phenyl)-5-methyl-1H-[1,2,3]triazole-4-carboxylic acid 7-methyl-2-oxo-3-phenyl-2,3-dihydro-thiazolo[4,5-b]pyridin-5-yl ester (14). Yield: 75\%, $\mathrm{mp} .=180{ }^{\circ} \mathrm{C} .{ }^{1} \mathrm{H}$ NMR (400 MHz, DMSO-d6) d 2.01 (s, $\left.3 \mathrm{H}, \mathrm{C}_{6} \mathrm{H}_{3}-\mathrm{CH}_{3}\right), 2.12\left(\mathrm{~s}, 3 \mathrm{H}, \mathrm{C}_{6} \mathrm{H}_{3}-\mathrm{CH}_{3}\right), 2.37$ (s, 3H, $\left.\mathrm{CH}_{3}\right)$, $3.08\left(\mathrm{~s}, 3 \mathrm{H}\right.$, triazole $\left.-\mathrm{CH}_{3}\right), 6.96\left(\mathrm{~d}, 1 \mathrm{H}, J=8.0 \mathrm{~Hz}, \mathrm{C}_{6} \mathrm{H}_{3}\right)$, 7.04 (s, 1H, Py), 7.30 (t, J=7.4 Hz, J=7.7 Hz, 2H, $\mathrm{C}_{6} \mathrm{H}_{5}$ ), $7.32-7.35\left(\mathrm{~m}, 1 \mathrm{H}, \mathrm{C}_{6} \mathrm{H}_{3}\right), 7.46\left(\mathrm{~d}, J=8.1 \mathrm{~Hz}, 3 \mathrm{H}, \mathrm{C}_{6} \mathrm{H}_{5}\right)$, 7.83-7.85 (m, $\left.1 \mathrm{H}, \mathrm{C}_{6} \mathrm{H}_{3}\right)$. Anal. calcd. for: $\mathrm{C}_{25} \mathrm{H}_{21} \mathrm{~N}_{5} \mathrm{O}_{3} \mathrm{~S}: \mathrm{C}$ 63.68, H 4.49, N 14.85. Found: C 63.57, H 4.52, N 14.71.

1-(2-Chloro-phenyl)-5-methyl-1H-[1,2,3]triazole-4-carboxylic acid 7-methyl-2-oxo-3-phenyl-2,3-dihydro-thiazolo[4,5-b]pyridin-5-yl ester (15). Yield: $69 \%, \mathrm{mp} .=171{ }^{\circ} \mathrm{C}$. ${ }^{1} \mathrm{H}$ NMR (400 MHz, DMSO-d6) d 2.33 (s, 3H, CH $)$ ), 3.05 (s, $3 \mathrm{H}$, triazole $\left.-\mathrm{CH}_{3}\right), 6.91-6.96\left(\mathrm{~m}, 1 \mathrm{H}, \mathrm{C}_{6} \mathrm{H}_{4}\right), 7.00$ (s, $1 \mathrm{H}, \mathrm{Py}), 7.28\left(\mathrm{t}, J=7.4 \mathrm{~Hz}, J=7.7 \mathrm{~Hz}, 2 \mathrm{H}, \mathrm{C}_{6} \mathrm{H}_{5}\right), 7.41-7.49$ 
$\left(\mathrm{m}, 1 \mathrm{H}, \mathrm{C}_{6} \mathrm{H}_{4}\right), 7.43\left(\mathrm{~d}, J=8.1 \mathrm{~Hz}, 3 \mathrm{H}, \mathrm{C}_{6} \mathrm{H}_{5}\right), 7.55-7.58$ (m, $2 \mathrm{H}, \mathrm{C}_{6} \mathrm{H}_{4}$ ). Anal. calcd. for: $\mathrm{C}_{23} \mathrm{H}_{16} \mathrm{ClN}_{5} \mathrm{O}_{3} \mathrm{~S}$ : C 57.80, H 3.37, N 14.65. Found: C 57.88, H 3.35, N 14.59.

1-(3,4-Dimethyl-phenyl)-5-methyl-1H-[1,2,3]triazole-4-carboxylic acid 7-methyl-2-oxo-3-phenyl-2,3-dihydro-thiazolo[4,5-b]pyridin-5-yl ester (16). Yield: 69\%, $\mathrm{mp} .=171{ }^{\circ} \mathrm{C} .{ }^{1} \mathrm{H}$ NMR (400 MHz, DMSO-d6) d 2.08 (s, $\left.3 \mathrm{H}, \mathrm{C}_{6} \mathrm{H}_{3}-\mathrm{CH}_{3}\right), 2.13\left(\mathrm{~s}, 3 \mathrm{H}, \mathrm{C}_{6} \mathrm{H}_{3}-\mathrm{CH}_{3}\right), 2.34\left(\mathrm{~s}, 3 \mathrm{H}, \mathrm{CH}_{3}\right)$, $3.07\left(\mathrm{~s}, 3 \mathrm{H}\right.$, triazole- $\left.\mathrm{CH}_{3}\right), 6.86\left(\mathrm{~d}, 1 \mathrm{H}, J=8.0 \mathrm{~Hz}, \mathrm{C}_{6} \mathrm{H}_{3}\right)$, 7.05 (s, 1H, Py), 7.13-7.17 (m, 2H, J = 7.2 Hz, $\left.\mathrm{C}_{6} \mathrm{H}_{3}\right), 7.25$ $\left(\mathrm{t}, J=7.4 \mathrm{~Hz}, J=7.7 \mathrm{~Hz}, 2 \mathrm{H}, \mathrm{C}_{6} \mathrm{H}_{5}\right), 7.44(\mathrm{~d}, J=8.1 \mathrm{~Hz}, 3 \mathrm{H}$, $\mathrm{C}_{6} \mathrm{H}_{5}$ ). Anal. calcd. for: $\mathrm{C}_{25} \mathrm{H}_{21} \mathrm{~N}_{5} \mathrm{O}_{3} \mathrm{~S}: \mathrm{C} 63.68, \mathrm{H} 4.49, \mathrm{~N}$ 14.85. Found: C 63.75, H 4.43, N 14.80.

General procedure for the preparation of s-alkylation products 7-methyl-2-oxo-3-phenyl-2,3-dihydrothiazolo[4,5-b] pyridin-5-yl ester of monochloroacetic acid (17-20). Into a round bottom flask was added $50 \mathrm{mmol}$ of compound $\mathbf{1 0}$, $50 \mathrm{mmol}$ of the corresponding thiol and $20 \mathrm{ml}$ of ethanol. The reaction mixture is refluxed for 1 hour. White crystalline precipitates that precipitate after cooling are filtered off and washed with ethanol. The compounds obtained are recrystallized from ethanol or acetic acid.

[4-Amino-5-(4-methyl-furan-3-yl)-4H-pyrazol-3ylsulfanyl]-acetic acid 7-methyl-2-oxo-3-phenyl-2,3-dihydro-thiazolo[4,5-b]pyridin-5-yl ester (17). Yield: 75\%, $\mathrm{mp} .=176{ }^{\circ} \mathrm{C} .{ }^{1} \mathrm{H}$ NMR (400 MHz, DMSO-d6) d 2.08 (s, 3H, furan- $\left.\mathrm{CH}_{3}\right), 2.31\left(\mathrm{~s}, 3 \mathrm{H}, \mathrm{CH}_{3}\right), 4.14 \mathrm{~s}\left(2 \mathrm{H}, \mathrm{CH}_{2}\right)$, $6.14\left(\mathrm{~s}, 2 \mathrm{H}, \mathrm{NH}_{2}\right), 7.01$ (s, $\left.1 \mathrm{H}, \mathrm{Py}\right), 7.11(\mathrm{~s}, 1 \mathrm{H}$, aryl), $7.28\left(\mathrm{t}, J=7.3 \mathrm{~Hz}, J=7.6 \mathrm{~Hz}, 2 \mathrm{H}, \mathrm{C}_{6} \mathrm{H}_{5}\right), 7.44(\mathrm{~d}, J=$ $\left.8.0 \mathrm{~Hz}, 3 \mathrm{H}, \mathrm{C}_{6} \mathrm{H}_{5}\right), 7.72$ (s, $1 \mathrm{H}$, aryl). Anal. calcd. for: $\mathrm{C}_{23} \mathrm{H}_{19} \mathrm{~N}_{5} \mathrm{O}_{4} \mathrm{~S}_{2}$ : C 55.97, H 3.88, N 14.19. Found: C 56.23, $\mathrm{H} 3.84, \mathrm{~N} 14.21$.

(5-Phenyl-[1,3,4]oxadiazol-2-ylsulfanyl)-acetic acid 7-methyl-2-oxo-3-phenyl-2,3-dihydro-thiazolo[4,5-b]pyridin-5-yl ester (18). Yield: $68 \%, \mathrm{mp} .=193{ }^{\circ} \mathrm{C} .{ }^{1} \mathrm{H}$ NMR (400 MHz, DMSO-d6) d 2.35 (s, 3H, $\left.\mathrm{CH}_{3}\right), 4.14$ (s, 2H, $\mathrm{CH}_{2}$ ), 7.00 (s, 1H, Py), 7.25 (t, $J=7.3 \mathrm{~Hz}, J=7.7 \mathrm{~Hz}, 2 \mathrm{H}$, $\left.\mathrm{C}_{6} \mathrm{H}_{5}\right), 7.39\left(\mathrm{~s}, 2 \mathrm{H}\right.$, oxadiazol- $\left.\mathrm{C}_{6} \mathrm{H}_{5}\right), 7.46(\mathrm{~d}, J=8.0 \mathrm{~Hz}$, $\left.3 \mathrm{H}, \mathrm{C}_{6} \mathrm{H}_{5}\right), 7.55\left(\mathrm{~s}, 1 \mathrm{H}\right.$, oxadiazol- $\left.\mathrm{C}_{6} \mathrm{H}_{5}\right), 7.80(\mathrm{~s}, 2 \mathrm{H}$, oxadiazol- $\mathrm{C}_{6} \mathrm{H}_{5}$ ). Anal. calcd. for: $\mathrm{C}_{23} \mathrm{H}_{16} \mathrm{~N}_{4} \mathrm{O}_{4} \mathrm{~S}_{2}$ : C 57.97, $\mathrm{H}$ 3.38, N 11.76. Found: C 58.09, H 3.36, N 11.64.

(1-p-Tolyl-1H-tetrazol-5-ylsulfanyl)-acetic acid 7-methyl-2-oxo-3-phenyl-2,3-dihydro-thiazolo [4,5-b]pyridin-5-yl ester (19). Yield: $75 \%, \mathrm{mp} .=169{ }^{\circ} \mathrm{C} .{ }^{1} \mathrm{H}$ NMR (400 MHz, DMSO-d6) d 2.01 (s, 3H, aryl- $\left.\mathrm{CH}_{3}\right), 2.33$ $\left(\mathrm{s}, 3 \mathrm{H}, \mathrm{CH}_{3}\right), 4.11\left(\mathrm{~s}, 2 \mathrm{H}, \mathrm{CH}_{2}\right), 6.98(\mathrm{~s}, 1 \mathrm{H}, \mathrm{Py}), 7.24(\mathrm{t}$, $\left.J=7.4 \mathrm{~Hz}, J=7.7 \mathrm{~Hz}, 2 \mathrm{H}, \mathrm{C}_{6} \mathrm{H}_{5}\right), 7.48(\mathrm{~d}, J=8.0 \mathrm{~Hz}, 3 \mathrm{H}$, $\left.\mathrm{C}_{6} \mathrm{H}_{5}\right), 7.54(\mathrm{~d}, 2 \mathrm{H}, J=8.8 \mathrm{~Hz}$, aryl), $7.71(\mathrm{~d}, 2 \mathrm{H}, J=8.8 \mathrm{~Hz}$, aryl). Anal. calcd. for: $\mathrm{C}_{23} \mathrm{H}_{18} \mathrm{~N}_{6} \mathrm{O}_{3} \mathrm{~S}_{2}$ : C 56.31, H 3.70, N 17.13. Found: C 56.25, H 3.74, N 17.21.

(Benzothiazol-2-ylsulfanyl)-acetic acid 7-methyl-2-oxo-3-phenyl-2,3-dihydro-thiazolo[4,5-b]pyridin-5-yl ester (20). Yield: $66 \%, \mathrm{mp} .=160{ }^{\circ} \mathrm{C} .{ }^{1} \mathrm{H}$ NMR $(400 \mathrm{MHz}$, DMSO-d6) d 2.33 (s, 3H, $\mathrm{CH}_{3}$ ), ), 4.07 (s, $2 \mathrm{H}, \mathrm{CH}_{2}$ ), 7.00 (s, $1 \mathrm{H}, \mathrm{Py}), 7.25$ (t, $\left.J=7.3 \mathrm{~Hz}, J=7.6 \mathrm{~Hz}, 2 \mathrm{H}, \mathrm{C}_{6} \mathrm{H}_{5}\right), 7.36$ $(\mathrm{t}, 1 \mathrm{H}, J=7.0 \mathrm{~Hz}, J=6,7 \mathrm{~Hz}, \mathrm{Ar}), 7.44(\mathrm{~d}, J=8.0 \mathrm{~Hz}, 3 \mathrm{H}$, $\left.\mathrm{C}_{6} \mathrm{H}_{5}\right), 7.50$ (t, 1H, J=7.2 Hz, J=6,7 Hz, Ar), 7.88 (d, 1H, Ar), 8.11 (d, $1 \mathrm{H}, \mathrm{Ar})$. Anal. calcd. for: $\mathrm{C}_{22} \mathrm{H}_{15} \mathrm{~N}_{3} \mathrm{O}_{3} \mathrm{~S}_{3}$ : C 56.76, H 3.25, N 9.03. Found: C 56.89, H 3.33, N 8.98.

\section{Anti-inflammatory activity}

The experiment was performed on nonlinear white rats of both sexes weighing 180-200 g. Rats were kept in the animal house under standard conditions of light and temperature on the general diet prior to the experiment. Total swelling was caused by aseptic injection of $0.1 \mathrm{ml}$ of a $2 \%$ solution of carrageenan under aponeurosis of the sole of the hind limb of the rat for $0.5 \mathrm{~h}$. animals were intraperitoneally injected with the test substance at a dose of $50 \mathrm{mg} / \mathrm{kg}$ prior to administration of the carrageenan solution. The presence of an inflammatory reaction was determined by changing the volume of the limb oncometric method at the beginning of the experiment and 4 hours after the introduction of the phlogogenic agent. For comparison, the anti-inflammatory effect of a known anti-inflammatory drug-ibuprofen in medium therapeutic doses was studied in similar conditions. The Ethics Committee of the Danylo Halytsky National Medical University, established by the Ministry of Health of Ukraine, approved the experimental protocol. The suppression of the inflammatory reaction was expressed as a percentage reduction in the volume of the paw, and it was calculated by the following equation:

$$
\% \text { Inhibition }=\frac{V_{\text {control }}-V}{V_{\text {control }}} \cdot 100 \%,
$$

where Vcontrol is the increase in paw volume in control group animals;

$\mathrm{V}$ is the increase in paw volume in animals injected with the test substances.

\section{Results and discussion}

\section{Chemistry}

Continuing the systematic study of thiazolo[4,5- $b]$ pyridines as potential anti-inflammatory agents, we have synthesized novel $\mathrm{N}^{3}$ and $\mathrm{C}^{5}$ substituted derivatives of 5-hydroxy-7-methyl-3H-thiazolo[4,5- $b]$ pyridin-2-one. Our new approach to the synthesis of thiazolo[4,5- $b]$ pyridines, which was based on the ability of 4-iminothiazolidin-2-one to react to $[3+3]$ cyclocondensation with dielectrophilic reagents (Chaban et al. 2012b, 2019b) was previously proposed synthesis of novel $\mathrm{N}$-aryl-substituted thiazolo[4,5- $b$ ] pyridin-2-ones. Previously obtained 3-aryl-4-iminothiazolidin-2-ones (Chaban et al. 2019c) due to their N,C-binucleophilic properties are able to cyclize with acetoacetic ether to form the corresponding 3-aryl-5-hydroxy-7-methyl-3H-thiazolo[4,5- $b$ ]pyridin-2-ones (1-8) (Figure 1). This conversion takes place in a methanol medium in the presence of sodium methylate and allows the introduction of aryl residues at the $\mathrm{N}^{3}$ position of the base scaffold. Experiments have shown that it is optimal to obtain compounds 1-8 with constant stirring of the reaction mixture for 5 days at a temperature of $20-25^{\circ} \mathrm{C}$.

To expand the combinatorial library of thiazolo $[4,5-b]$ pyridines, the transformation of 3-phenyl-5-hydroxy-7-me- 


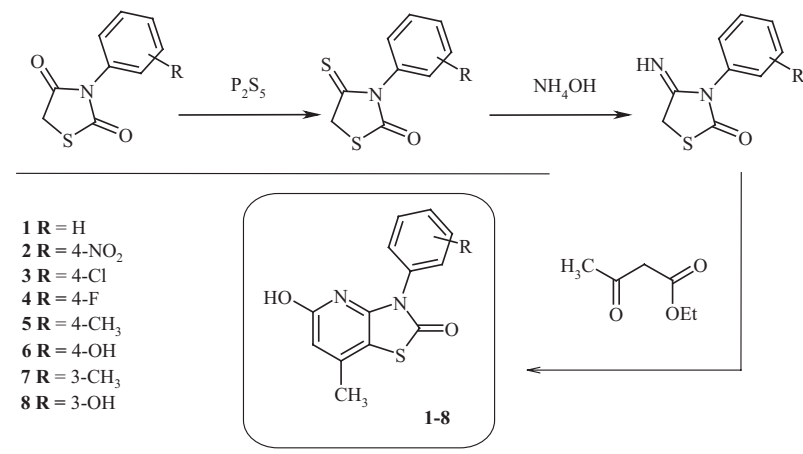

Figure 1. Synthesis of 3-aryl-5-hydroxy-7-methyl-3H-thiazolo[4,5-b]pyridin-2-ones.

thyl-3H-thiazolo[4,5-b]pyridin-2-one (1) at position $\mathrm{C}^{5}$ was performed. The synthetic potential of the hydroxy group of compound $\mathbf{1}$ is represented by its interaction with a series of carboxylic acid chlorides in an acylation reaction. It is established that the optimum conditions for obtaining the corresponding acylated derivatives of 3-phenyl-5-hydroxy-7-methyl-3H-thiazolo[4,5-b]pyridin-2-one (9-16) are the reaction in the environment of dioxane under interaction with aliphatic chlorides and pyridine in the case of interaction with aromatic chlorides (Figure 2).

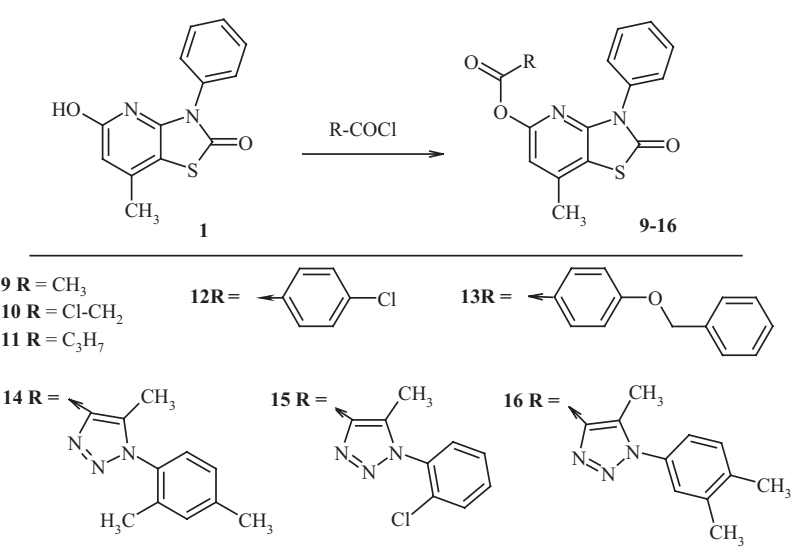

Figure 2. Synthesis of 7-methyl-3-phenyl-2-oxo-2,3-dihydrothiazolo[4,5-b]pyridin-5-yl 4-carboxylates.

Compound 10 may be considered as a key intermediate in 5-hetarylsulfanyl-acetic acid 7-methyl-2-oxo-3-phenyl-2,3-dihydro-thiazolo[4,5-b]pyridin-5-yl esters obtaining being treated with appropriate thiols. The reaction mixture reflux for $60 \mathrm{~min}$ in $96 \%$ ethanol medium were optimal conditions for compounds 17-20 formation proceeding in good yields (Figure 3 ). Thus the series of thiazolo[4,5-b] pyridin-2-one acetamides has been diversified by alkylation reactions applying compound $\mathbf{1 0}$ as alkylating agent employing it into the reactions with heteryl moiety thiols which can be considered an effective and general route to a wide range of acetamides preparation.

The structure of the compounds obtained and the interpretation of the chemical studies were confirmed by elemental analysis and 1H NMR spectroscopy. All these new compounds gave spectroscopic data in accordance with the proposed structures.
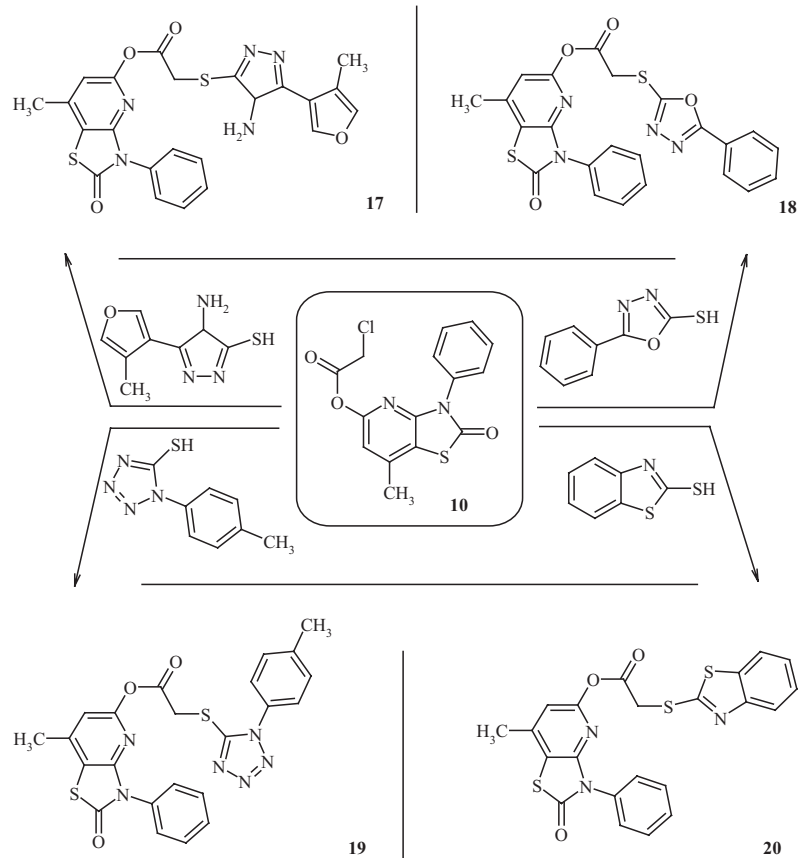

Figure 3. Synthesis of hetarylsulfanyl derivatives of chloro-acetic acid 7-methyl-2-oxo-3-phenyl-2,3-dihydro-thiazolo[4,5- $b$ ] pyridin-5-yl ester under the alkylation reaction.

\section{Anti-inflammatory activity in vivo eva- luation}

Exudative is considered to be a classic example of acute inflammation. The effect of the synthesized substances on the course of the exudative phase of inflammation was studied on the basis of a carrageenan model of inflammatory edema of the paws of white rats (Pillai et al. 2004).

In vivo studies of novel thiazolo[4,5- $b]$ pyridine-2-one derivatives were carried out for anti-inflammatory activity employing the carrageenan-induced rat paw edema method. Carrageenan-induced paw edema is the most common animal model of acute inflammation. Marked paw edema was caused in rats with sub-planter injection of $0.1 \mathrm{ml}$ of $2 \%$ carrageenan. Investigated compounds were dissolved in DMSO and injected intraperitoneally $50 \mathrm{mg} / \mathrm{kg}$ body weight $0.5 \mathrm{~h}$ prior to carrageenan injection. The NSAID drug Ibuprofen in its effective therapeutic dose was tested simultaneously as an activity reference. Anti-inflammatory activity was estimated by measuring the paw edema volume $4 \mathrm{~h}$ after the carrageenan injection. Results of paw edema decreasing were expressed as the average \pm standard deviation and compared statistically with the control group using Student's $\mathrm{t}$-test. A level of $\mathrm{p}<0.05$ was adopted as the test of significance (Table 1).

According to the anti-inflammatory activity pharmacological screening for synthesized products, in a significant number of cases the anti-inflammatory effect is equivalent to that of the reference drug Ibuprofen. For some compounds, the anti-inflammatory effect was less than the of the reference drug. The inflammatory response inhibition for them are in the range of $20.2-35.4 \%$. However, some substances activity exceeds Ibuprofen, which gives reason 
Table 1. Anti-inflammatory effect of thiazolo[4,5- $b]$ pyridine-2-ones on carrageenan-induced rat paw edema $(\mathrm{ml})$ in vivo evaluation, \% protection from inflammation.

\begin{tabular}{lccc}
\hline Compound ID & $\begin{array}{c}\text { Paw edema volume } \\
(\mathbf{m L}) \pm \text { SEM }^{*}\end{array}$ & \% Inhibition & Activity relative to Ibuprofen, \% \\
\hline Control & $2.20 \pm 0.050$ & - & \\
$\mathbf{1}$ & $1.27 \pm 0.020$ & 42.1 & 104.7 \\
$\mathbf{2}$ & $1.69 \pm 0.035$ & 23.2 & 57.7 \\
$\mathbf{3}$ & $1.06 \pm 0.015$ & 51.8 & 128.9 \\
$\mathbf{4}$ & $1.14 \pm 0.015$ & 48.3 & 120.2 \\
$\mathbf{5}$ & $1.66 \pm 0.035$ & 24.4 & 60.7 \\
$\mathbf{6}$ & $1.39 \pm 0.025$ & 36.7 & 91.3 \\
$\mathbf{7}$ & $1.71 \pm 0.040$ & 22.2 & 55.2 \\
$\mathbf{8}$ & $1.42 \pm 0.040$ & 35.4 & 88.1 \\
$\mathbf{9}$ & $1.68 \pm 0.035$ & 23.6 & 58.7 \\
$\mathbf{1 0}$ & $1.24 \pm 0.020$ & 43.5 & 108.2 \\
$\mathbf{1 1}$ & $1.74 \pm 0.040$ & 21.1 & 52.5 \\
$\mathbf{1 2}$ & $1.31 \pm 0.020$ & 40.5 & 100.8 \\
$\mathbf{1 3}$ & $1.75 \pm 0.040$ & 20.6 & 51.3 \\
$\mathbf{1 4}$ & $1.51 \pm 0.030$ & 31.2 & 77.6 \\
$\mathbf{1 5}$ & $1.38 \pm 0.025$ & 37.2 & 92.5 \\
$\mathbf{1 6}$ & $1.52 \pm 0.030$ & 30.8 & 76.6 \\
$\mathbf{1 7}$ & $1.71 \pm 0.040$ & 22.1 & 55.0 \\
$\mathbf{1 8}$ & $1.69 \pm 0.035$ & 23.4 & 58.2 \\
$\mathbf{1 9}$ & $1.76 \pm 0.040$ & 20.2 & 50.3 \\
$\mathbf{2 0}$ & $1.72 \pm 0.040$ & 21.8 & 54.2 \\
$\mathbf{I b u p r o f e n}$ & $1.32 \pm 0.035$ & 40.2 & 100 \\
\hline & & &
\end{tabular}

to consider this condensed system as a promising molecular framework for the design of potential anti-inflammatory agents.

The results of pharmacological screening and analysis of the structure of molecules and the nature of the substituents in different positions of the thiazolopyridine cycle allow us to distinguish a number of patterns of dependence «structure - anti-inflammatory action» among the derivatives of thiazolo[4,5- $b]$ pyridin-2-one.

5-Hydroxy-7-methyl-3-phenyl-3H-thiazolo[4,5-b] pyridin-2-one exhibits relatively not very high anti-inflammatory activity - 36.2\% (Chaban et al. 2019b). However, the possibility of its structural modification according to the $\mathrm{N}^{3}$ and $\mathrm{C}^{5}$ positions of the base scaffold creates prerequisites for rational design in order to search for "drug-like" compounds with a high level of anti-inflammatory activity. Carrying out structural modification by positioning $\mathrm{N}^{3}$ allowed to obtain the corresponding 3-aryl-5-hydroxy-7-methyl-3H-thiazolo[4,5-b]pyridin-2-ones, which increases activity compared to the base scaffold. Structural modification at $\mathrm{C}^{5}$ allows to isolate only 2 compounds that, in terms of activity, approach or exceed the Ibuprofen comparator. The acylation products exhibited different anti-inflammatory activity as determined by the nature of the substituent. The resulting S-alkylation products of 7-methyl-2-oxo-3-phenyl-2,3-dihydrothiazolo[4,5-b] pyridin-5-yl ester of monochloroacetic acid (17-20) have no anti-inflammatory activity.

The results obtained demonstrate that the anti-inflammatory effect of the synthesized compounds is probably due to the contribution of 5-hydroxy-7-methyl-3-phenyl-3H-thiazolo[4,5-b]pyridine nucleus and a number of structural fragments that are pharmacophore for the class heterocycles and the type of pharmacological activity.

\section{Conclusions}

As a result of the $[3+3]$ cyclocodensation, acylation and alkylation reactions, the synthesis of novel thiazolo[4,5- $b]$ pyridin-2-ones has been carried out. For the synthesized compounds, in vivo screening of anti-inflammatory activity was conducted, the results of which indicate that the test substances in terms of activity approach or exceed the preparation of the comparison Ibuprofen. Thus the core thiazolo $[4,5-b]$ pyridine heterocyclic system may be regarded as a promising scaffold for the effective anti-inflammatory a drug candidates development.

\section{References}

Abhinit M, Ghodke M, Pratima N (2009) Exploring potential of 4-thiazolidinone: a brief review. International Journal of Pharmacy and Pharmaceutical Sciences 1: 47-64. https://innovareacademics.in/ journal/ijpps/Vol\%201\%20Issue\%201/122.pdf.

Ali Altaf A, Shahzad A, Gul Z, Rasool N, Badshah A, Lal B, Khan E (2015) A review on the medicinal importance of pyridine derivatives. Journal of Drug Design and Medicinal Chemistry 1(1): 1-11. https:// doi.org/10.11648/j.jddmc.20160201.11

Al-Shidhani A, Al-Rawahi N, Al-Rawahi A, Murthi S (2015) Anti-inflammatory drugs (NSAIDs) use in primary health care centers in a'seeb, muscat: a clinical audit. Oman Medical Journal 30(5): 366371. https://doi.org/10.5001/omj.2015.73

Bacchi S, Palumbo P, Sponta A, Coppolino M (2012) Clinical pharmacology of non-steroidal anti-inflammatory drugs: a review. Anti-Inflammatory \& Anti-Allergy Agents in Medicinal Chemistry 11: 52-64. https://doi.org/10.2174/187152312803476255

Brenner PS, Krakauer T (2003) Regulation of Inflammation: A review of recent advances in anti- inflammatory strategies. Current Medicinal Chemistry2(3):274-283.https://doi.org/10.2174/1568014033483752

Chaban TI, Panchuk RR, Klenina OV, Skorokhyd NR, Ogurtsov VV, Chaban IG (2012a) Synthesis and evaluation of antitumor activity of some thiazolo[4,5- $b$ ] pyridines. Biopolymers and Cell 28: 389-396. https://doi.org/10.7124/bc.000075

Chaban TI, Zimenkovskii BS, Komaritsa JD, Chaban IG (2012b) Reaction of 4-iminothiazolidin-2-one with acetylacetone. Russian Journal of Organic Chemistry 48(2): 268-272. https://doi.org/10.1134/ S1070428012020170

Chaban TI, Ogurtsov VV, Chaban IG, Klenina OV, Komarytsia JD (2013) Synthesis and antioxidant activity evaluation of novel 5,7-dimethyl-3H-thiazolo[4,5- $b$ ]pyridines Phosphorus, Sulfur and Silicon and the Related Elements 188: 1611-1620. https://doi.org/10.1080/1 0426507.2013 .777723

Chaban T, Klenina O, Drapak I, Ogurtsov V, Chaban I, Novikov V (2014) Synthesis of some novel thiazolo[4,5- $b]$ pyridines and their tuberculostatic activity evaluation. Chemistry and Chemical Technology 89: 287-292. https://doi.org/10.23939/chcht08.03.287

Chaban TI, Klenina OV, Zimenkovsky BS, Chaban IG, Ogurtsov VV, Shelepeten LS (2016) Synthesis of novel thiazolo[4,5-b]pyridines as 
potential biologically active substances. Der Pharma Chemica 8(19): 534-542. https://www.derpharmachemica.com/pharma-chemica/ synthesis-of-novel-thiazolo-45b-pyridines-as-potential-biologically-active-substances.pdf

Chaban Z, Harkov S, Chaban T, Klenina O, Ogurtsov V, Chaban I (2017a) Recent advances in synthesis and biological activity evaluation of condensed thiazoloquinazolines: A review. Pharmacia 64(3): 52-66. http:// bsphs.org/?magasine=recent-advances-in-synthesis-and-biological-activity-evaluation-of-condensed-thiazoloquinazolines-a-review

Chaban T, Klenina O, Harkov S, Ogurtsov V, Chaban I, Nektegaev I (2017b) Synthesis of some new $\mathrm{N}^{3}$ substituted 6-phenylazo-3H-thiazolo[4,5-b]pyridin-2-ones as possible anti-inflammatory agents. Pharmacia 64(4): 16-30. http://bsphs.org/?magasine=synthesis-of-some-new-n3-substituted-6-phenylazo-3\%d0\%bd-thiazolo45-bpyridin-2-ones-as-possible-anti-inflammatory-agents

Chaban T, Klenina O, Chaban I, Ogurtsov V, Harkov S, Lelyukh M (2018a) Thiazolo[5,4- $d]$ pyrimidines and thiazolo $[4,5-d]$ pyrimidines: A review on synthesis and pharmacological importance of their derivatives. Pharmacia 65(2): 54-70. http://bsphs.org/?magasine=thiazolo54-dpyrimidines-and-thiazolo45-dpyrimidines-a-review-on-synthesis-and-pharmacological-importance-of-their-derivatives

Chaban T, Matiychuk V, Ogurtsov V, Chaban I, Harkov S, Nektegaev I (2018b) Synthesis and biological activity of some novel derivatives 5,7-dimethyl-6-phenylazo-3H-thiazolo[4,5- $b$ ]pyridine-2-one. Pharmacia 65(4): 51-62. http://bsphs.org/?magasine=synthesis-and-biological-activity-of-some-novel-derivatives-57-dimethyl-6-phenylazo-3\%d0\%bd-thiazolo45-bpyridine-2-one

Chaban T, Ogurtsov V, Mahlovanyy A, Sukhodolska N, Chaban I, Harkov S, Matiychuk V (2019a) Antioxidant properties of some novel derivatives thiazolo[4,5-b]pyridine. Pharmacia 66(4): 171-180. https://doi.org/10.3897/pharmacia.66.e36764

Chaban TI, Ogurtsov VV, Matiychuk VS, Chaban IG, Demchuk IL, Nektegayev IA (2019b) Synthesis, anti-inflammatory and antioxidant activities of novel $3 H$-thiazolo[4,5- $b]$ pyridines. Acta Chimica Slovenica 66: 103-111. https://doi.org/10.17344/acsi.2018.4570

Chaban T, Ogurtsov V, Chaban I, Myrko I, Harkov S, Leluykh M (2019c) Synthesis of some new 4-iminothiazolidine-2-ones as possible antioxidants agents. Pharmacia 66(1): 27-32. https://doi.org/10.3897/ pharmacia.66.e35131

Chhabria MT, Patel S, Modi P, Brahmkshatriya PS (2016) Thiazole: A review on chemistry, synthesis and therapeutic importance of its derivatives. Current Topics in Medicinal Chemistry 16: 2841-2862. https://doi.org/10.2174/1568026616666160506130731

Hegde SG, Mahoney MD (1993) Synthesis and herbicidal activity of 5-(haloalkyl)-substituted thiazolo[4,5- $b]$ pyridine-3(2H)-acetic acid derivatives. Journal of Agricultural and Food Chemistry 41: 2131 2134. https://doi.org/10.1021/jf00035a058

Klenina O, Drapak I, Chaban T, Ogurtsov V, Chaban I, Golos I (2013) QSAR studies of some thiazolo[4,5-b]pyridines as novel antioxidant agents: enhancement of activity by some molecular structure parameters. Chemistry and Chemical Technology 7: 397-404. https://doi. org/10.23939/chcht07.04.397

Klenina O, Chaban T, Zimenkovsky B, Harkov S, Ogurtsov V, Chaban I, Myrko I (2017) Qsar modeling for antioxidant activity of novel $\mathrm{N}^{3}$ substituted 5,7-dimethyl-3H-thiazolo[4,5- $\left.b\right]$ pyridin-2-ones. Pharmacia 64(4): 49-71. http://bsphs.org/?magasine=qsar-model- ing-for-antioxidant-activity-of-novel-n3-substituted-57-dimethyl-3\%d0\%bd-thiazolo45-bpyridin-2-ones

Komoriya S, Kobayashi S, Osanai K, Yoshino T, Nagata T, Haginoya N, Nakamoto Y, Mochizuk A, Nagahara T, Suzuki M, Shimada T, Watanabe K, Isobe Y, Furugoori T (2006) Design, synthesis, and biological activity of novel factor Xa inhibitors: Improving metabolic stability by S1 and S4 ligand. Bioorganic and Medicinal Chemistry 5: 13091330. https://doi.org/10.1016/j.bmc.2005.09.056

Lin R, Johnson SG, Connolly PJ, Wetter SK, Binnun E, Hughes TV, Murray WV, Pandey NB, Moreno-Mazza SJ, Adams M, Fuentes-Pesquera AR, Middleton SA (2009) Synthesis and evaluation of 2,7-diamino-thiazolo[4,5- $d$ ] pyrimidine analogues as antitumor epidermal growth factor receptor (EGFR) tyrosine kinase inhibitors. Bioorganic and Medicinal Chemistry Letters 19: 2333-2337. https://doi. org/10.1016/j.bmcl.2009.02.067

Lozynska L, Tymoshuk O, Chaban T (2015) Spectrophotometric studies of 4-[n'-(4-imino-2-oxo-thiazolidin-5-ylidene)-hydrazino]-benzenesulfonic acid as a reagent for the determination of Palladium. Acta Chimica Slovenica 62: 159-167. https://doi.org/10.17344/ acsi.2014.866

Marzoog S, Al-Thebeiti (2000) Synthesis of some new thiazolo[3,2-a] pyridines and related heterocyclic systems. Il Farmaco 55: 109-118. https://doi.org/10.1016/S0014-827X(99)00130-5

Pillai AD, Rathod PD, Franklin PX, Padh H, Vasu KK, Sudarsanam V (2004) Design, synthesis, and SAR studies of some 5-aliphatic oximinoesters of thiophene as potential anti-inflammatory leads:comparative biological activity profile of aliphaticoximes vs aromatic oximes. Biochemical and Biophysical Research Communications 317: 1067-1074. https://doi.org/10.1016/j.bbrc.2004.03.148

Singh B, Bacon ER, Lesher GY, Robinson S,.Pennock PO, Bode DC, Pagani ED, Bentley RG, Connell MJ, Hamel LT, Silver PJ (1995) Novel and potent adenosine 3',5'-cyclic phosphate phosphodiesterase III inhibitors: thiazolo[4,5- $b][1,6]$ naphthyridin-2-ones. Journal of Medicinal Chemistry 38(14): 2546-2550. https://doi.org/10.1021/ jm00014a007

Smirnova NG, Zavarzin IV, Krayushkin MM (2006) Synthesis of condensed thiazoles. Chemistry of Heterocyclic Compounds 42: 144165. https://doi.org/10.1007/s10593-006-0064-8

Taylor AP, Robinson RP, Fobian YM, Blakemore DC, Jones LH, Fadeyi $\mathrm{O}$ (2016) Modern advances in heterocyclic chemistry in drug discovery. Organic \& Biomolecular Chemistry 14(28): 6611-6637. https:// doi.org/10.1039/C6OB00936K

Tymoshuk O, Oleksiv L, Khvalbota L, Chaban T, Patsay I (2019) Spectrophotometric determination of ru(iv) using 5-hydroxyimino-4-imino-1,3-thiazolidin-2-one as a novel analytical reagent. Acta Chimica Slovenica 66: 62-69. https://doi.org/10.17344/acsi.2018.4448

Victor V, Semenov B, Lichitsky V, Komogortsev N, Dudinov A, Krayushkin M (2017) Synthesis and anti-mitotic activity of 6,7-dihydro- $4 H$-isothiazolo[4,5-b]pyridin-5-ones: In vivo and cell-based studies. European Journal of Medicinal Chemistry 125: 573-585. https://doi.org/10.1016/j.ejmech.2016.09.075

Walczyn'ski K, Zuiderveld OP, Timmerman H (2005) Non-imidazole histamine H3 ligands. Part III. New 4-n-propylpiperazines as non-imidazole histamine H3-antagonists. European Journal of Medicinal Chemistry 40: 15-23. https://doi.org/10.1016/j.ejmech.2004.09.010 